DOI: $10.12957 /$ transversos.2021.47123

\title{
A CIDADE DO LOBITO NA MEMÓRIA DE MIGRANTES DA DESCOLONIZAÇÃO DE ANGOLA RESIDENTES NO RIO DE JANEIRO THE CITY OF LOBITO IN THE MEMORY OF MIGRANTS OF DECOLONIZATION FROM ANGOLA WHO LIVE IN RIO DE JANEIRO
}

Isabel de Souza Lima Junqueira Barreto

Universidade Federal Fluminense (UFF) - Brasil isljbarreto@gmail.com

\section{Resumo:}

A cidade do Lobito foi fundada em 1905. Segundo o último Censo populacional do período colonial em Angola, feito em 1970, naquela altura era a terceira maior cidade angolana. Era um centro econômico muito relevante, sede de um importante porto e do Caminho de Ferro de Benguela. Este artigo aborda as memórias de antigos habitantes que residem hoje no Rio de Janeiro e que deixaram Angola em 1975, ano da independência política e do início da guerra civil. Através de suas lembranças foi possível acessar a visão que tinham da atmosfera da cidade, um exemplo da visão da vida em Angola como um paraíso, assim como suas visões a respeito do racismo e da discriminação estruturantes daquela sociedade. Tal questão se referia às relações entre brancos e negros e também entre colonos, de primeira geração e luso-angolanos.

Palavra-Chaves: Memória; Angola; Lobito;

Discriminação Racial.

\section{Abstract}

The city of Lobito was founded in 1905. According to the last population census, made in 1970, at that time it was the third biggest Angolan city. It was a very relevant economic center, headquarters of an important port and of the Benguela Railway. This paper approach the memories of former inhabitants that today live in Rio de Janeiro and who left Angola in 1975, year of the political independence and the beginning of the civil war. Through their memories it was possible to access their vision of the city's atmosphere, an example of the vision concerning the life in Angola as a paradise, as well as their visions concerning the structural racism and discrimination of that society. Such matter refers to the relation between whites and blacks and also between first generation settlers and luso-angolans.

Keywords: Memory; Angola; Lobito; Racial Discrimination.

\section{Introdução}

Em 1970, segundo o último censo populacional do período colonial, feito naquele ano, o Lobito era uma cidade com 59.528 habitantes, sendo 14.152 brancos, 2.780 mestiços e 42.567 negros. Era a terceira cidade mais povoada de Angola atrás de Luanda e Huambo (antiga Nova Lisboa) (REPÚBLICA PORTUGUESA - ESTADO DE ANGOLA, 1973: p. 8). Seu porto era, no período colonial, o porto mais importante da costa ocidental da África. De lá sai o importante Caminho de Ferro de Benguela, doravante CFB, que teve sua a outra extremidade inaugurada em Luau, na República Democrática do Congo em 1929. Atualmente liga o Lobito à cidade de Tenque. Sua construção foi iniciada em 1899. A cidade foi fundada em 1905. A história da cidade é muito ligada ao porto e a construção do Caminho de Ferro. 
Os informantes de quem as memórias serão aqui citadas nasceram ou viveram na cidade $^{1}$. Suas memórias transitam pela percepção de viver em um paraíso, um paraíso colonial, mas também pela lembrança do preconceito que sofriam dos portugueses por terem nascido em Angola e do racismo vivenciado pela população "indígena" ${ }^{2}$, a maioria esmagadora da população. No período compreendido entre o fim da guerra de independência e sua consolidação, a população branca de Angola se dispersou entre vários países. Representavam apenas 5\% da população, mas eram a maioria dos ocupantes de postos tecnicamente qualificados que mantinham a economia do país funcionando. A saída maciça dessa parte da população levou ao abandono de pequenos negócios bem como de fazendas que produziam para o mercado interno, ocasionando uma profunda crise econômica. $\mathrm{Na}$ fase final do império colonial português, Angola era, juntamente com a África do Sul, a Rodésia do Sul (hoje Zimbabwe) e Moçambique o que se pode chamar de "bastião branco da África Austral. Em 1974 Angola possuía a segunda maior população branca de todo o continente africano, número superado apenas pela África do Sul” (PEIXOTO, 2015: p. 17).

A saída em massa de portugueses e luso-angolanos se deu através da instalação de uma ponte aérea Luanda-Lisboa. Foi encerrada poucos dias depois do 11 de Novembro de 1975, data da independência. Seu auge foram os meses de setembro e outubro daquele ano. No sul, houve um expressivo número de pessoas que decidiu cruzar a fronteira com a Namíbia. Esperavam uma solução rápida para o conflito. Expectativa que foi frustrada. Os que atravessaram a fronteira foram instalados em campos de refugiados por militares sul-africanos. Entre fevereiro e abril de 1976 foi criada uma ponte-aérea Windhoek-Lisboa, que repatriou 11.000 pessoas. Estima-se que 60\% dos que deixaram a África em direção a Portugal saíram de Angola. A maior parte dos que se fixaram em Portugal "retornaram para as comunidades de onde haviam saído alguns anos antes ou de onde um membro familiar imediato havia migrado originalmente”. (PEIXOTO, 2015: p. 163). Uma parcela desses migrantes, instalou-se no Brasil. Sua entrada foi garantida com a posse do visto de turistas. Segundo dados do Anuário Estatístico do Brasil, Publicado pelo Instituto

\footnotetext{
${ }^{1}$ Os nomes dos entrevistados aqui citados são pseudônimos.

${ }^{2}$ O Estatuto Político, Civil e Criminal dos Indígenas de Angola e Moçambique, de 1926, no seu artigo 3o define como "indígenas", negros ou seus descendentes que não tenham adotado códigos culturais do colonizador português. Havia todo um conjunto de instituições à parte que regulava a vida desse grupo, entre elas estava a Repartição Superior de Negócios Indígenas. A diferenciação que sofriam era ainda marcada pela obrigatoriedade do pagamento do imposto indígena de captação e do porte da "caderneta indígena" instituída também em 1926. Cf. (NETO, 1997: p. 345; BITTENCOURT, 2010).
} 
Brasileiro de Geografia e Estatística (IBGE), em 1975, entraram no país 38.485 pessoas com esse visto de nacionalidade portuguesa (BARRETO, 2014). Tendo vindo diretamente de Angola ou após passagens pela África do Sul, Namíbia e Portugal.

Glaucia, nasceu na cidade em 1951. Filha de um português e uma luso-angolana. Seu pai trabalhou, entre outros lugares, em uma companhia de café e uma refinaria belga de Petróleo. Lá viveu até os 18 anos. Em 1969 foi estudar medicina em Portugal. Retornou a Angola em 1971, continuando seus estudos em Luanda por um ano. Foi professora de ciências. Casou-se em 1973 com Ricardo. Deixou Angola em outubro de 1975, quando chegou ao Brasil acompanhada do marido. Ao chegarem no Rio de Janeiro encontraram um ambiente favorável. Tiveram apoio da estrutura montada pela Federação das Associações Portuguesas e Luso-Brasileiras na cidade, que envolvia as casas regionais. Foram recebidos pela Casa da Vila da Feira e Terras de Santa Maria. De lá foram encaminhados para outra instituição, a Banda Lusitana. Se naturalizou brasileira após a promulgação da Constituição de 1988.

Ricardo também nasceu no Lobito em 1948. Seu avô paterno era português, foi exilado para Angola no princípio do século XX, mas seu pai havia nascido em Angola. Ambos foram despachantes aduaneiros. Possui ensino liceal completo. Ao terminar os estudos serviu o exército. Deu baixa em 1974. Viveu o último ano em Angola em Luanda. Chegou ao Brasil em outubro de 1975 com Glaucia. Com a ajuda recebida conseguiu um emprego em um supermercado ainda em novembro. Naturalizou-se brasileiro após a promulgação da Constituição de 1988.

Tomás é brasileiro, nascido em Niterói em 1948, mas mudou-se para Angola em 1955. A família viveu um ano no Lobito, depois se mudaram para Benguela. Lá permaneceram por um ou dois anos. Após esse período voltou com a família para o Lobito, onde permaneceu até 1969. Seus pais eram portugueses. Era neto de um industrial do ramo da pesca. Ao terminar os estudos foi convocado para servir o exército na guerra colonial. Deu baixa em 1972 voltando para o Brasil. Retornou a Angola no ano seguinte. Chegou ao Brasil indo se instalar na cidade de Vitória, onde haveria suporte da família da esposa. Chegou acompanhado da esposa e de uma filha.

Lorena é médica. Nasceu na cidade do Lobito em 1951. Filha de um economista e de uma administradora de empresas. Seus pais, ambos portugueses, chegaram a Angola em 1947 e 1948. Inicia seus estudos superiores em Angola, mas os completa na Universidade Federal do Paraná, em Curitiba. Chega ao Brasil em 1975 acompanhada do marido e da filha. Ao chegar 
desembarcou em São Paulo, mas fixou residência em Curitiba, onde terminou a faculdade de medicina.

Augusto nasceu em 1951. É filho de pais de classe média nasceu numa missão de um médico norte americano no interior a setenta quilômetros de Nova Lisboa, atual Huambo. Filho de um contador e uma dona de casa viveu em diferentes cidades como Luanda, Huambo e Lobito, onde a mãe passou a trabalhar no ramo de estética. Estudou na escola industrial. É neto de portugueses que migraram no princípio do século XX. Chegou ao Brasil entre setembro e outubro de 1975. Veio acompanhado da mãe, que em cerca de um ou dois meses foi para Portugal, onde estava sua outra filha. Foi muito bem recebido no Rio de Janeiro, onde encontrou trabalho em uma construtora pouco tempo depois da chegada. Não obteve auxílio da estrutura criada pela comunidade portuguesa. Viveu em outras cidades brasileiras como Natal e Salvador.

Como é possível verificar são, todos, de uma mesma geração e classe social. Cito suas memórias, pois, quando as ouvimos, "ouvimos a maneira como as pessoas pensam que experimentaram suas vidas e certos eventos, tantas são as transformações que dependem de quem está falando com quem" (LEYDESDORFF, 2000: p. 78).

Paul Thompson (2002) pontuou duas finalidades para as quais a História Oral é utilizada. Por um lado, há o estudo de acontecimentos políticos que não são possíveis de serem investigados por outros meios, dado o fato de serem recentes. Não há, portanto, fontes oficiais escritas desclassificadas o suficiente. Assim, as fontes orais dialogam com a imprensa, por exemplo. Por outro há as biografias. Este artigo utiliza três tipos de fontes primárias, a memória de luso-angolanos nascidos na cidade, um episódio da série de documentários Angola 70, produzida pela Rádio e Televisão de Portugal (RTP), intitulado Benguela - Lobito e reportagens publicadas no Jornal de Angola ${ }^{3}$ na década de 1950.

A memória como sabemos é seletiva. É vasta a bibliografia que aborda a questão. No caso das memórias dos migrantes da descolonização, ou seja, ex-colonos e seus descendentes nascidos nas colônias, que deixaram a África com o fim do colonialismo (SMITH, 2003), a fuga de Angola configura um momento traumático de suas vidas. As memórias da vida em Angola

\footnotetext{
${ }^{3}$ Trata-se do jornal de Propriedade da Associação dos Naturais de Angola (Anangola), formada, sobretudo, por mestiços, mas entre seus membros havia também negros e brancos. Não confundir com o antigo jornal A Provincia de Angola, fundado em 16 de agosto de 1923 e refundado como Jornal de Angola em 1975. Sua publicação se inicia em 1953. Sua periodicidade inicialmente era mensal, posteriormente passando a ser quinzenal. Em fins de 1962 não era mais vendido, porém, distribuído gratuitamente aos sócios (BITTENCOURT, 2010; BOSSLET, 2014).
} 
nunca morreram. Fazendo uma analogia com as lembranças insones dos sobreviventes do holocausto, sobre a confiabilidade na seleção do que lembrar feita pelos informantes é possível dizer "depoimentos constituem documentos humanos, muito mais do que históricos, a interação perturbada entre passado e presente atinge uma gravidade que ultrapassa a preocupação com a exatidão" (ROSEMAN, 2000: p.124).

\section{A história da cidade do Lobito e as memórias de informantes que nela nasceram ou} viveram

Quando foi fundada, em 1905, a cidade não passava de um pequeno lugarejo. O episódio Bengela - Lobito da série de documentários Angola 70, produzida pela RTP, na sua metade final, dedicada à cidade, se centra basicamente na atividade portuária. Localizado na Baía do Lobito, com cerca de $5 \mathrm{~km}$ de extensão, movimentava cerca de dois milhões de toneladas de mercadorias da Província de Benguela e dos países vizinhos. Os gêneros alimentícios angolanos exportados eram milho, sisal, crueira, frutas entre outros víveres. No que se refere à importação, desembarcavam no porto petróleo, vinhos, materiais de construção civil, maquinaria agrícola, entre outros. O porto beneficiava também a atual República Democrática do Congo, e a Zâmbia. Através do $\mathrm{CFB}$, que se liga à rede ferroviária transafricana, eram escoados minérios, mais especificamente manganês, cobre, zinco, entre outros. Com destino a ambos os países desembarcava mercadoria diversa e outros materiais. No porto ainda havia atividades de reparo de embarcações de muitas nacionalidades. Sobre o porto e o CFB, Gláucia, relata nas suas memórias:

Ali naquele porto é entravam e saíam mercadorias. Algumas iam até no caminho-deferro atravessava a África até Moçambique que é o Oceano Indico, então fazia conexão de Atlântico com o Índico, né, havia transferência de mercadorias, saía dali minérios para outros lugares, para o Japão, inclusive, não era? (Entrevista com Glaucia, Rio de Janeiro, 05 de maio de 2011)

Uma reportagem, intitulada O Lobito, do Jornal de Angola em sua edição de 28 de fevereiro de 1954 aborda a importância ganha pela Baía do Lobito, em 1903, devido à construção do CFB que, em 1928 chegou ao Congo Belga. O empreendimento foi responsável pelo desenvolvimento das regiões por ele travessadas nas províncias de Benguela e do Bié. O Porto e o CFB foram os empreendimentos econômicos que impulsionaram o crescimento da cidade, mas o texto salienta outras indústrias importantes como a de cimento bem como a produção de sal. A arquitetura moderna da cidade também é destacada. Tanto no que se refere aos edifícios públicos quanto aos residenciais. Ainda sobre a economia da cidade, ligadas à atividade marítima, 
são citadas as presenças de estaleiros que atuam como coadjuvantes da indústria da pesca tão importante no distrito de Benguela.

Outra reportagem, da mesma edição, intitulada "O Lobito uma linda cidade um grande porto da África Ocidental" se remete também à importância da baía e do porto para o desenvolvimento da cidade. As instalações, cobrindo 20.000 metros quadrados em 1952 receberam 709 navios que carregavam 859.968 toneladas de mercadorias. Em 1954, ano da reportagem, o movimento do porto havia aumentado para 860 navios e o cais tinha sido aumentado para 148 metros de extensão sendo prevista a construção de mais 264 metros para navios de grande calado e cabotagem. Outra reportagem, "Damos a palavra aos números e às cifras respeitantes a Angola” destaca outra indústria em franco crescimento, a construção civil. Tal ramo passou a ter um crescimento exponencial desde 1945. Estatísticas oficiais de 1953 informavam que em naquele ano foram construídos 674 edifícios. Destes 100 ficavam no Lobito.

Em 1952 terminou de ser construída, na cidade, a Companhia de Cimentos de Angola. Era possível vê-la de toda a cidade. Uma reportagem de 30 de Junho de 1954 intitulada "Um colosso de cimento e de aço na cidade do Lobito”, cobriu a visita oficial do General Craveiro Lopes e do Ministro do Ultramar, Comandante Sarmento Rodrigues que ocorreu em 19 de Junho de 1954. Acompanhavam os visitantes os administradores da companhia, Anselmo Vilandebô e Carlos Sommer Champalimaud, o Governador da província de Benguela, o Presidente da Câmara Municipal do Lobito além de convidados, jornalistas e fotógrafos.

No pós-Segunda Guerra houve investimentos maciços na infraestrutura das possessões africanas capitaneados pelo governo metropolitano. Neste panorama foram criados em Lisboa o Gabinete de Urbanização Colonial (GUC, 1944), posteriormente renomeado como Gabinete de Urbanização do Ultramar (GUU). O órgão, que estava sob a alçada do Ministério do Ultramar. Era ali que se esboçava o planejamento urbano das cidades da África portuguesa até 1957, quando passam a ser responsabilidade da Direção dos Serviços de Urbanização e Habitação (Direção Geral de Obras Públicas e Comunicações). A aplicação da aprendizagem racionalista do pósguerra pôde ser observada, no caso angolano, nas cidades e Luanda e do Lobito. O período entre 1945 e a década de 1970 "baliza assim a produção moderna na África portuguesa, apesar da existência de práticas progressistas e de espírito higienista desde os anos trinta" (MILHEIRO, 2009: p. 61). 
Recorro novamente às memórias de Gláucia que contou que a cidade parecia um jardim com uma língua de terra e restinga. Destaca que a cidade tinha uma atmosfera festiva e que por conta do porto circulavam pessoas de diferentes nacionalidades, com quem se fazia amizades, muitas delas europeias. Destaca também a geografia da cidade e a distribuição dos bairros, alguns perto da restinga e outros em regiões mais centrais:

Então é uma cidade boa, uma cidade boa de se viver, sabe? É como se fosse assim um,
um jardim. Era uma cidade tranquila, festiva, sabe? Com a a ...bastante gente de outras
nacionalidades circulando por conta do porto, então havia gente, é... sei lá muito
europeu passando de vez em quando por ali. Havia amizade, que a gente tinha amizade
com gente de, de outros países também, né, por conta dessa questão de ter o porto de
mar. Era uma cidade animada, tinha festa o tempo todo (...) uma língua de terra que
entra, sai da costa e entra pelo mar, então isso é que formava esse grande porto, sabe.
Então, essa língua de terra, ali tinha mar de um lado e mar do outro. Tinha bairros ali
e tinha uns bairros mais afastados. Essa parte que era a restinga e tinha é, bairros mais
centrais e tinha bastante comércio, né, bastante comércio (Entrevista com Gláucia, Rio
de Janeiro, 5 de maio de 2011).

Gláucia e seu marido Ricardo abordam o lazer da cidade ao comentarem sobre as atividades esportivas. Lembraram dos esportes náuticos como Remo, Vela, Ski aquático, Iatismo, dos clubes onde havia treinamento de ginastas, e dos clubes de futebol (Entrevista com Ricardo e Gláucia, 05 de Maio de 2011).

Augusto deixou o Huambo aos sete anos de idade. Se mudou para o Lobito, cidade na qual viveu até os vinte anos. Depois, mudou-se para Luanda, onde viveu até deixar Angola em 1975. Deixou Angola, portanto, com 24 anos. Das cidades nas quais viveu, gostava mais do Lobito, pois tinha "umas praias muito bonitas sem ninguém, era uma vida tranquila. Era uma cidade de dimensões humanas. Luanda já era demasiado cidade grande”. Sobre a vida em Angola sua percepção é de que "era uma vida normal. Com a vantagem de ser uma terra muito grande com pouca gente, portanto, havia a vantagem do espaço. Era uma vida saudável, não tínhamos atropelos, de espécie nenhuma. Era uma espécie de paraíso”. (Entrevista com Augusto, Rio de 05 de Junho de 2011)

A História Oral permite explorar a construção da memória dos migrantes da descolonização que passaram muito tempo negligenciados pela historiografia portuguesa. Segundo Maurício da Silva Selau (2004: p. 221) "Por tratar-se de uma operação intelectual, a história permite o distanciamento, a crítica e a reflexão sobre as memórias. Para tanto, dispõe de determinado conjunto de procedimentos metodológicos”. A memória social sobre o período é majoritariamente construída por ex-combatentes e por migrantes da descolonização (SMITH, 2003) que através da publicação de suas memórias pessoais por meio de livros ou websites na 
internet vão construindo a memória coletiva do período. A História Oral permite uma reconstituição da história desse grupo sob uma ótica crítica tratando o discurso dos informantes de forma objetiva. Sendo assim suas histórias de vida são um corpus documental relevante para quem se dedica à história do fim do Terceiro Império português.

Os lugares são um dos três elementos constitutivos da memória juntamente com os acontecimentos e os personagens segundo Michael Pollak (1992). Para Paul Thompson, embora toda fonte histórica seja subjetiva a fonte oral permite que essa subjetividade seja desafiada, pois permite "descolar as camadas da memória, cavar fundo em suas sombras, na expectativa de atingir a verdade oculta" (2002: p. 197). As fontes orais permitem a construção da história de um certo lugar a partir do cruzamento das memórias individuais com outras fontes documentais disponíveis. Sobre essa questão aponta Joan del Alcàzar i Garrido:

Um dos aspectos mais interessantes do uso de fontes orais é que não apenas se chega a
um conhecimento dos fatos, mas também à forma como o grupo os vivenciou e
percebeu. É de importância capital resgatar a subjetividade, mas é um grave erro passar
a confundi-la com fatos objetivos. Esta aproximação crítica ao testemunho oral
consegue-se mediante dois procedimentos de caráter interativo: um, com a
documentação escrita existente, e outro, com o resto do corpus de documentos orais.
Daí a importância de se estabelecer uma relação dialética entre os diversos tipos de
fontes (GARRIDO, 1992-1993: p. 39).

Sobre a atmosfera da cidade, em 31 de Julho de 1954 o Jornal de Angola publica outra reportagem sobre sob o título "O Lobito uma cidade moderníssima cujo crescimento causa admiração". A cidade originalmente chamada de "Catumbela da Água Salgada" ou "Catumbela das Ostras" na década de 1950 era considerada uma das mais "civilizadas cidades de Angola". Segundo o autor da reportagem, Ernesto de Oliveira, a atmosfera da pequena cidade não era provinciana. Seus habitantes tinham um apreço muito grande por atividades esportivas diversas. Economicamente, devido à presença do porto, a cidade era uma das que mais crescia em Angola. Em cinquenta anos deixou de ser "uma língua de areia deserta, com o mar de um lado e pântanos do outro”. Naquele momento só havia uma edificação, o Chalet do Governador Geral onde funcionavam os serviços aduaneiros do porto, então insipiente. Outra edificação de destaque da cidade foi a sede da Associação Comercial, Industrial e Agrícola do Lobito-Catumbela. Tendo começado a funcionar na Catumbela como um simples agrupamento de comerciantes teve seu estatuto aprovado em 1923. Sua sede no Lobito foi inaugurada em 11 de junho de 1954, pelo Secretário Geral de Angola, José António Fernandes. A reportagem ainda destaca o Campo de Aviação, o segundo mais movimentado de Angola, só ficando atrás do de Luanda. As palavras que encerram a reportagem dão conta da atmosfera relembrada por Gláucia acima: 
É tudo isto: o seu Palácio da Associação Comercial, o seu Campo de Aviação, que é, depois do de Luanda, o de maior movimento de toda a Província, a sua baía magnífica, com o seu bem apetrechado porto, as suas ruas bem traçadas e cuidadas, marginadas de esplendidos prédios, a sua posição de términus da linha de Caminho de Ferro mais importante da Província, as suas indústrias, a sua vida comercial intensa, a densidade da sua população branca, desempoeirada e civilizada, tudo isto, obtido em menos de 50 anos, faz realmente do Lobito uma cidade diferente (JORNAL DE ANGOLA, 1954: 11)

\section{A importância do Caminho de Ferro de Benguela (CFB)}

O Caminho de Ferro de Benguela foi idealizado pelo engenheiro escocês Robert Williams. A linha férrea proposta tinha $1400 \mathrm{~km}$ de extensão e ligava Lobito a Tenque no então Congo Belga. Naquela conjuntura era unanimidade ser importante a construção de uma ferrovia na África Central. O governo de Lisboa tinha um fundo para a sua construção. Haviam sido feitos estudos pelo engenheiro Joaquim José Machado, que tinha sido indicado pela Sociedade de Geografia de Lisboa. O objetivo de Robert Williams, entretanto, era ter uma via por onde escoar a produção de uma mina no Katanga cuja concessão ele havia negociado com Leopoldo II da Bélgica. O trajeto do CFB era $2700 \mathrm{~km}$ mais curto do que as melhores alternativas existentes naquele momento, Beira e Cabo (TAVARES; SILVA, 2002). Para alcançar seu objetivo:

Robert Williams propôs ao Governo português a construção do caminho-de-ferro, seguindo a antiga "picada" por onde, a pé, de tipoia às costas de nativos, ou de galera puxada por bois, se subia ao planalto e se penetrava em direcção ao coração de África. Em contrapartida, Robert Williams (ou melhor, a recém-formada Companhia do Caminho-de-Ferro de Benguela), explorava a via durante 99 anos e tinha o exclusivo de minérios e madeiras numa faixa de 120 quilómetros para cada lado da linha, para além de outras facilidades fiscais e aduaneiras (TAVARES; SILVA, 2002: p. 04).

O contrato foi assinado e em 1911 o CFB chegou ao Huambo, antiga Nova Lisboa. A obra foi interrompida com a Primeira Guerra Mundial. Seu último trecho foi inaugurado em 1929. Os caminhos de ferro tiveram um impacto profundo na economia do continente africano bem como na sua geografia. Fizeram a ligação do interior do continente com seu litoral. Dessa forma, matérias-primas eram escoadas por um porto para o mercado internacional. Com a exploração de minas de ouro, de diamantes, de cobre e de carvão na África Central e Austral houve uma grande mudança econômica e sociocultural.

A cidade do Lobito foi escolhida como local de seu ponto de partida no litoral devido à descoberta de minas de cobre no Katanga em 1901. A 28 de novembro de 1902, o governo de Lisboa firma acordo com a Tanganyka Concessions Limited. A construção, iniciada em 1903, só veio a ter fim em 1928. À medida que sua construção avançou, houve descontentamento da população nativa, pois, seu traçado passava por terras habitadas por povos que se viram espoliados das suas terras, cedidas a imigrantes europeus. Na prática isso significou a ocupação militar e 
administrativa do Planalto Central. Em paralelo havia o objetivo de incentivar a migração de colonos para a região. Com isso buscava-se desenvolver uma agricultura de plantação, com o cultivo de café e algodão. Como resultado houve o aumento da população europeia na região, a fundação de cidades ${ }^{4}$, a abertura de fábricas e a consolidação da construção do CFB (RELÓGIO; TAVARES; PACHECO, 2020).

Segundo Tomás, o CFB "foi destruído durante a guerra. Era a maior estrada de Ferro que existia em África. Existe até hoje. Ela sai do Porto do Lobito (...) essa estrada de ferro ficou simplesmente parada porque explodiu e agora tá sendo recuperada" (Entrevista com Tomás, Rio de Janeiro, 19 de maio de 2012). Além disso, impulsionou o crescimento de Benguela e Huambo, sem contar, é claro, o desenvolvimento do Lobito. Assim sendo todo o seu percurso passou por uma grande transformação urbana. O pai de Lorena, uma das nossas interlocutoras chegou a ser convidado para trabalhar no CFB:

\begin{abstract}
Meu pai era economista, minha mãe tinha um outro curso de formação administrativa, administração de empresas. Meu pai trabalhava em finanças e ele sempre gostou muito de ensino, educação, sempre foram muito sociais, sempre estiveram envolvidos em coisas sociais também. Ele recebeu vários convites, um deles para multinacional dos caminhos de ferro, trem, e o outro para dirigir o Instituto Superior de Educação do Bié, no Centro de Angola. (...) foi por volta de 47, 48. E com essa ideia de educação ele foi pro Bié. Aceitou ser diretor lá, a minha mãe ficou como professora e ele como diretor (Entrevista com Lorena, Rio de Janeiro, 3 de julho de 2011).
\end{abstract}

Claudia Castelo (2007) aborda a importância da Companhia do Caminho de Ferro de Benguela (CCFB) para o povoamento da região com migrantes vindos de Portugal a partir da segunda metade da década de 1930. Ao se falar na categoria colono é necessário ter em mente que, referia-se a homens adultos nascidos em Portugal. Não era recomendável a ida de crianças entre 5 e 16 anos de idade. As mulheres poderiam migrar se tivessem boa resistência física. Eram consideradas fundamentais para a colonização. Sua presença era importante para garantir a "dignidade dos colonos em África”. Além disso garantiria "a reprodução da família cristã". A existência de filhos mestiços eram consideradas fontes de perturbações sociais. No que se refere à escolaridade e profissão, o colono deveria, pelo menos, saber ler, escrever e ter um ofício (CASTELO, 2007: p. 249). Sobre esta questão, Adolfo Maria, ex-membro do Movimento Popular de Libertação de Angola (MPLA), em entrevista a Fernando Pimenta (2006), diz que em 1950 havia apenas dois liceus em Angola. Na visão do regime do Estado Novo em Angola devia-se trabalhar, não fazer política. (MARIA apud PIMENTA, 2006: p. 35). Como consequência disso,

\footnotetext{
${ }^{4}$ O CFB protagonizou o surgimento de cidades ao longo da sua extensão. Entre elas estão Cáala, Luena, Cuíto e Luau, denominadas Robert Williams, Luso, Silva Porto e Teixeira de Sousa respectivamente no período colonial.
} 
os colonos eram politicamente "amorfos" e não tinham como fazer frente ao papel a eles reservado, o de instrumentos do regime colonial. Havia apenas uma escassa minoria muito politizada.

Álvaro Machado, secretário-geral da Sociedade de Geografia de Lisboa e administrador delegado da CCFB, em 1934, escreveu um relatório a respeito das possibilidades de fixação de europeus ao longo da linha férrea. Dado o contexto internacional do período e a presença de europeus de outras nacionalidades como alemães, italianos e poloneses nas regiões da Ganda, do Chinguar e do Quipeio, Machado defendia a "fixação de indivíduos da metrópole nos pontos mais ameaçados" (CASTELO, 2007: p. 99). O decreto 25.027 de 2 de setembro de 1935 deu início ao processo. Buscava-se mostrar que o Estado através de investimentos poderia manter a migração para a colônia. De acordo com o decreto:

(...) o governo geral de Angola fará demarcar na zona de influência do Caminho de Ferro de Benguela, para a fixação de colonos europeus, um ou mais lotes de terreno próprio para cultura e pastagens, com superfície não inferior a 400 hectares; cada lote será dividido em talhões com cerca de 200 hectares; cada talhão terá uma área de 60 hectares para culturas; a escolha dos lotes far-se-á por acordo entre as autoridades locais e a companhia; os talhões serão objecto de concessão provisória a colonos indicados pela companhia; a concessão provisória durará 11 anos, após os quais o colono fica com direito à concessão definitiva. A Companhia compromete-se a entregar ao colono, à chegada, o terreno desbravado, uma horta em condições de fornecer os principais géneros hortículas de alimentação, uma seara semeada e uma habitação de pau a pique; o Estado pagará a passagem aos colonos e respectivas famílias da metrópole até o Lobito; a Companhia transporta-os até o destino e assegura-lhes assistência técnica e médica, o transporte de mercadorias e a aquisição das colheitas (DIÁRIO DO GOVERNO apud CASTELO, 2007: p. 99).

Em 1935 houve 673 interessados. Em 1936 foram escolhidos os primeiros três colonos.

Em 1937 foram instalados mais quatro colonos. Em 1938 e 1939 instalaram-se dois colonos por ano. Durante este período houve desistências, mas também uma expulsão. Em 1949 a experiência é encerrada. Como resultado tem-se nove famílias instaladas. A Companhia realizou, em 1939, um inquérito à colonização agrícola europeia livre que se estabeleceu na região do Caminho de Ferro de Benguela. Outro inquérito analisado versava sobre a situação dos colonos da experiência de colonização do CCFB, em 1946. A comparação de ambos permitiu concluir que a colonização livre era preferível e mais barata em relação à colonização promovida pela CCFB (CASTELO, 2007). Os colonos que se dedicavam apenas à agricultura viviam com dificuldades. Sua situação não era pior que a vivida por trabalhadores rurais em Portugal. Só quem trava comércio com os povos locais consegue uma situação melhor. A maior parte dos colonos não tem a propriedade 
da terra que cultiva, alguns vivem "em condições deprimentes, coabitando com indígenas" (CCFB apud CASTELO, 2007: p. 104-105).

Outra iniciativa promovida pelo Estado Novo para a fixação de migrantes em solo africano foi a criação de colonatos-modelo. O mais representativo deles foi o Colonato da Cela, no Planalto de Amboim, Cuanza-Sul. Tal fato se deve a diferentes razões: investimento, número de famílias instaladas, divulgação na imprensa e propaganda. Em 1951 começaram as obras. Em 1953 chegaram os primeiros colonos. As condições de vida eram insalubres: “as casas já construídas não tinham mobílias, não havia água canalizada, estavam proibidos de recrutar mãode-obra indígena para os ajudar nos trabalhos agrícolas e nos trabalhos domésticos" (CASTELO, 2007: p. 144).

Devem ser citadas ainda as Juntas Provinciais de Povoamento (JPP). Foram criadas em 6 de setembro de 1961. Seus funcionamentos começaram em 1962. Em solo angolano "começou a funcionar já em conjuntura de guerra e depois de ter sido decretada a livre circulação de pessoas dentro de todo o território nacional português" (CASTELO, 2007: p. 154). Com isso, o órgão deveria responder de forma rápida aos pedidos de migração de centenas de indivíduos oriundos do meio rural, principalmente, e sem qualificações e profissão definida. Essas pessoas foram encaminhadas para a agro-pecuária. Foram criados núcleos de povoamento e foram aproveitadas estruturas já existentes em alguns serviços do governo provincial ou distritais. Esses núcleos funcionavam de acordo com normas muito rígidas para disciplinar os colonos e também aumentar a produção. Havia colonos que não respeitavam o contrato. "tratavam mal os trabalhadores assalariados, estavam desmotivados e não se adaptavam ao esquema imposto" (CASTELO, 2007: p. 157).

Aqui se deve abrir um parêntese para abordar a questão da segregação racial e o racismo na sociedade colonial angolana e a espoliação de terras cedidas a imigrantes europeus. Novamente recorremos a Claudia Castelo (2007). De acordo com a primeira, a ocupação das terras foi um dos problemas mais graves gerados pelo povoamento de Angola com metropolitanos. Desde os finais do século XIX, a legislação colonial previa a concessão das melhores terras aos colonos. Havia um grupo de políticos metropolitanos que eram contrários a tais medidas, por exemplo, Norton de Matos. Estes defendiam a criação de uma classe de pequenos proprietários rurais. Com esse fim, entre 1945 e 1946 criou-se o colonato de Caconda. Desde os anos 20, e principalmente nos anos 1950, trabalhadores agrícolas europeus que chegavam, ocupavam legal ou ilegalmente 
as terras. A escassez de terras levou Ovimbundos a se empregarem no distrito de Cuanza Norte como força de trabalho remunerada em plantações de brancos ou em pequenas plantações de café de outros africanos.

Recuando um pouco no tempo, à década de 1920, em nome da "missão civilizadora" que Portugal teve que se adaptar à nova concepção de política colonial do pós-Primeira Guerra Mundial. A partir de então, entendia-se que as potências coloniais deveriam desenvolver os territórios sob seu domínio e civilizar os povos colonizados. Neste sentido, o país se viu obrigado a por em prática "políticas de desenvolvimento econômico e a conceder maior autonomia política e administrativa às colónias, o que no caso de Angola e Moçambique se traduz na criação do cargo de alto-comissário da República” (CASTELO, 2007: p. 62). A pressão internacional para que essa "missão colonizadora" se dê dentro dos novos preceitos se tornou maior quando um relatório elaborado pelo sociólogo americano Edward Ross, em 1925, a pedido da Comissão sobre Escravismo da Sociedade das Nações constata e denuncia práticas próximas da escravidão nos territórios colonizados por Portugal (CASTELO, 2007).

Adolfo Maria, destaca duas formas importantes de como o colonialismo português foi um elemento importante para a formação da Nação em Angola: "destruturação das sociedades africanas e na integral submissão das gentes e território à lei colonial” e o fato de A debilidade econômica e política de Portugal, traduziram-se em formas de dominação específicas. O colonialismo português exercia a autoridade sobre as populações locais diretamente, através dos chamados "chefes de posto" e os meios repressivos que tinha a seu dispor. Devido à escassez de pessoal foram usados quadros administrativos mestiços e negros de famílias que tinham prosperado economicamente no comércio com o interior e no tráfico de escravos. "Durante bastante tempo, a noção de Angola como Nação difundiu-se quase só ao nível desta elite (por alguns dita "crioula") que, por fim, veio a dirigir o novo Estado, a partir de 1975" (MARIA apud PIMENTA, 2006: p. 29-30). Desta forma, o entrevistado refuta a noção de que o colonialismo português era soft em comparação ao exercido por outras metrópoles coloniais. Segundo ele havia várias subjetividades e contradições: metrópole/colônia, populações dominadas/população dominadora, entre as diferentes populações que habitam Angola, dominantes/dominados em cada povo, conflitos de interesse dentro de cada população. "A resistência sempre partiu das populações negras, pois, foram invadidas”. Segundo Carolina Peixoto (2015: p. 32-33):

Os africanos foram transformados em súbditos indígenas a quem o Estado colonial impunha deveres, mas outorgava poucos ou nenhuns direitos. $\mathrm{O}$ mito da superioridade 
do homem branco, dos seus saberes e experiências assumiu um lugar estratégico na arquitetura da dominação da África e dos africanos. A moderna política colonial-fascista portuguesa passou a discriminar inclusive os brancos nascidos nas colônias. Consequentemente, a sociedade angolana mergulhou numa complexa trama de tensões raciais.

A questão é percebida de diferentes formas pelos informantes. Há aqueles que reconhecem a existência do racismo no norte do país, a região das fazendas de café. Para outros não havia racismo entre as pessoas da sua geração. No primeiro caso está Gláucia, no segundo, Augusto, por último Tomás.

Havia muita exploração do negro nessa região [norte]. Inclusive, nós em Cabinda víamos isso. Os negros em Cabinda eram mais mal tratados. Eu lembro que a gente foi lá um dia e, e tinha uma fila para entrar no, no açougue. E, e os próprios negros estavam na fila nos faziam entrar na frente. Eu disse "não, eu fico na fila", o açougueiro veio me buscar para me atender ali porque os negros ficavam um pouco de lado. E nós, como estamos habituados no sul a ser de outra maneira acabou que a gente acabava conquistando esse pessoal, por conta exatamente desse diferencial que a gente dava, entendeu? (Entrevista com Gláucia, Rio de Janeiro, 05 de maio de 2011)

Angola não havia racismo. Estou a falar da minha geração, não estou a falar da geração do meu avô, como todos os colonos, havia colonos bons e colonos maus, não sei, tá? Eu estou a falar pela minha geração (Entrevista com Augusto, 05 de Junho de 2011).

A vida lá era melhor. Era muito mais tranquilo (...) todo mundo se dava bem, branco, amarelo. (...). A gente via coisas horrorosas, como [cara] levando chicotada. Quando eu era pequeno eu vi e até hoje eu tenho, eu tenho trauma. Mas o fato é que eu diria que a vida lá era melhor porque nós tínhamos uma vida mais tranquila. (...) Então, eu digo que a vida lá era melhor, não havia assim aquela brutalidade, um cara muito rico um cara muito pobre (...)" (Entrevista com Tomás, maio de 2011).

Os três trechos acima mostram percepções que reconhecem a existência do racismo. A vida "mais tranquila" o era para os colonos e suas famílias que, apesar da estratificação econômica, por serem colonos tinham uma situação social privilegiada. A percepção de Lorena mostra como os migrantes da descolonização encaram a vida em Angola como uma vivência em um paraíso, um paraíso colonial:

Angola era um país maravilhoso. Hoje tá um pouco conturbado, por outro lado era um país maravilhoso. Era um país muito grande, muito rico, como é o Brasil, afinal, eles tiveram séculos no passado, no passado foram juntos né, por conta dos continentes a separar-se e com muito pouca densidade populacional. Naquela época, já na época que eu era grande, era 1 milhão e meio de pessoas para um país enorme. Então não havia ... os portugueses que foram pra lá foram e eram conhecidos até por isso, embora em Portugal brincassem, diziam que eram "brancos de segunda”, né, havia essa brincadeira, mas foram para se radicar. E não foram propriamente ... não eram nem criminosos ... não, eram portugueses que queriam ir para um espaço maior, queriam ter outra vida e foram pra se radicar lá. Então criaram uma sociedade onde eles investiam, onde eles produziam, nunca senti racismo, a primeira vez que eu ouvi falar de cor foi quando eu cheguei ao Brasil, na verdade. Eu cresci no meio da floresta, no meio das savanas, dormindo com o bichos à volta, com fogueira pros leões não se aproximarem, andando atrás dos elefantes pra eles verem, a fazer pinturas com um amigo que pintava, meu pai tirava fotografias, eu revelava as fotografias junto com meu pai, quando já era maiorzinha, mais velhinha. Tivemos a oportunidade de dormir é em algumas tribos (...) 
que não foram salvas do extermínio pela imigração portuguesa e agora infelizmente estão cada vez mais ... os bosquímanos também e assistir a rituais únicos.

Então, eu diria que foi uma vida inesquecível, porque eu tive uma vivência dum planeta que está em extinção, que nós, seres humanos estamos a acabar com ele (Entrevista com Lorena, 03 de Julho de 2011).

Muitas questões podem ser comentadas a partir dessa fala de Lorena, mas vou me ater à sua percepção a respeito do que vem a ser "branco de segunda". Essa é uma outra faceta da sociedade nas antigas colônias portuguesas. A discriminação não pautava apenas a relação colonizador/colonizado. Pautava também a relação entre os migrantes de primeira geração e os descendentes de portugueses nascidos nas colônias. Adolfo Maria, na mesma entrevista a Fernando Pimenta (2006) fala sobre esta questão. Até a década de 1930, havia uma tensão entre a elite da minoria branca e o governo de Lisboa, que às vezes tomava "formas concretas de desobediência às autoridades de Lisboa” (MARIA apud PIMENTA, 2006: p.38).

Nos demais estratos sociais existia uma antipatia, pode-se dizer até mesmo oposição, entre muitos brancos nascidos em Angola e colonos recém-chegados. Tal sentimento se acentuou ao longo da década de 1950. Tal oposição tinha fundamentação econômica e social bem como ideológica. Ambos competiam por postos de trabalho, tanto no que se referia a postos públicos e privados. As burguesias local e metropolitana também competiam (PIMENTA, 2006). Segundo Carolina Peixoto (2015), aos novos colonos eram reservadas melhores terras produtoras de café. Os descendentes de portugueses nascidos em Angola, os "brancos de segunda”, eram também rotulados de "Euro-Africanos", designação que apareceu pela primeira vez no Recenseamento Geral da População de Angola de 1940. Foram, portanto, relegados a uma posição subalterna em relação aos colonos recém-chegados. Tal fato aproximava-os dos mestiços, com quem identificavam-se, pois, partilhavam escolas, associações culturais e ideias políticas (PIMENTA, 2008; PEIXOTO, 2015).

Ao contrário da percepção de Lorena de que se tratava de uma "brincadeira", a percepção de Ricardo é de que tratava-se do que essa categorização realmente é, uma hierarquização, uma inferiorização social por se tratar de cidadãos portugueses nascidos em territórios coloniais. Ao abordar a questão o interlocutor desconstrói a identidade metropolitana que assenta a noção de "missão colonizadora" do português, ou seja, o fato de serem europeus e brancos, ao evocar a herança muçulmana:

Agora, no entanto, havia sim uma diferença entre os portugueses de Portugal e os portugueses de Angola. Eles consideravam portugueses brancos de Angola os "brancos de segunda”. Tem essa diferença, só que eles se esquecem que eles foram colonizados, 
pelo menos a parte sul, pelos árabes. Então eles não são tão brancos quanto eles pensam (Entrevista com Ricardo, 05 de maio de 2011).

O mesmo interlocutor aborda a questão do racismo em relação aos negros e a reação dos luso-angolanos à categorização deles como "brancos de segunda":

Havia sempre gente racista, principalmente portugueses. Aqueles "boçais de Trás as Pedras" como a gente dizia ah, que principalmente em fazendas. Eles exploravam muito os negros. Tanto que o exército português controlava isso. Era uma das coisas que a gente fazia também no mato (Entrevista com Ricardo, 05 de Maio de 2011).

A questão do racismo e da relação conflituosa entre portugueses e luso-angolanos mostra a complexidade da realidade colonial. Para muitos dos luso-angolanos a chegada incessante de novos colonos portugueses a partir da década de 1950:

\begin{abstract}
arrogantes e cheios de preconceitos raciais quer contra os negros e mestiços, quer contra os brancos nados e criados em Angola, representava uma afronta e uma humilhação. Existia, realmente, um sentimento de alteridade: nós éramos angolanos, eles (os novos colonos) eram "matarroanos" e "besugos", isto é, portugueses! (MARIA apud PIMENTA, 2006: p. 38)
\end{abstract}

Tais questões foram importantes para a formulação de uma identidade angolana separada da portuguesa. Novamente recorremos a Adolfo Maria, que enumerou para além da oposição à ideia da independência pela maioria da população branca, e a existência de um significativo grupo de pessoas "amorfas" politicamente, cinco posicionamentos distintos sobre a questão. Tais posicionamentos eram: o desprezo pela metrópole, a hostilização de novos colonos sem, entretanto, ter familiaridade com o conceito de independência; o apoio à independência, desde que com a predominância política e econômica dos brancos com integração das elites mestiça e negra assimiladas; uma independência tal como a da antiga Rodésia do Sul, atual Zimbabwe, defendida pelo setor conservador da burguesia angolana; A independência da totalidade da população, com a elite luso-angolana como condutora. Esta posição era defendida por um setor liberal da burguesia. Por último havia um grupo de intelectuais progressistas, influenciado por ideias de esquerda, partidário da entrega do poder à maioria negra (Maria apud PIMENTA, 2006: p. 39-40).

Durante o processo foram criados inúmeros postos de trabalho. Na sua primeira fase estes não foram preenchidos por trabalhadores nativos, mas sim por mão de obra vinda de outras regiões da África Ocidental, Central e Austral, tais como Libéria, Gana, Serra Leoa, Cabo Verde, República Democrática do Congo e a Província de Natal, de países europeus, entre eles Portugal, Reino Unido, Espanha e Itália além da Índia. Entre os postos de trabalho abertos destacavam-se os de mecânico, serralheiro, eletricista, maquinista, condutor, maquinista, guarda-freios, assentador de via, agulheiro, fogueiro, contabilista, guarda de passagem de nível, entre outros. $\mathrm{Na}$ 
segunda fase da construção o quadro de contratações passou a contar majoritariamente com trabalhadores nativos. Jovens que terminavam seus estudos primários nas missões recorriam ao CFB para obterem o primeiro emprego a partir daí aprenderem uma profissão até se tornarem ferroviários. (PACHECO; RELÓGIO; TAVARES, 2017)

Já na década de 1960 houve grandes transformações na economia angolana. O desenvolvimento econômico dessa fase se deveu às alterações na política colonial. O Pacto Colonial foi substituído pelo Espaço Econômico Português, que integrou economicamente a metrópole e as antigas colônias. Se em 1905 foram transportadas apenas 759 pessoas, em 1973 passaram por aquela estação ferroviária 1.592.602 indivíduos. Quanto ao volume de mercadorias que por lá circularam para 1961 tem-se 3.507.125 toneladas e para 1973, 3.279.439 toneladas. Durante a guerra civil, iniciada em 1975, as atividades do CFB foram totalmente paralisadas. Em 1973, o CFB tinha cerca de 12.000 funcionários, transportava mais de 3,2 milhões de toneladas de carga e gerava 30 milhões de dólares em receita de transporte. Com o princípio da guerra civil e a independência política, seus funcionários qualificados fugiram. Os projetos de construção e manutenção foram interrompidos. (PACHECO; RELÓGIO; TAVARES, 2017).

\section{Conclusão}

Michael Pollak (1992) nos lembra que a memória constitui a identidade individual e coletiva "na medida em que ela é também um fator extremamente importante do sentimento de continuidade e de coerência de uma pessoa ou de um grupo em sua reconstrução de si” (POLLAK, 1992: p. 204). Paul Thompson (2002) ao refletir sobre a memória e a construção do eu evoca a importância do diálogo com a psicanálise, pois a história oral lida com memórias que podem ou não ser dolorosas, com silêncios, com emoções diversas. É preciso então que o historiador oral saiba escutar. Recordar "é fundamental para o nosso sentimento de identidade" (THOMPSON, 2002: p. 208). A evidência oral, segundo o mesmo autor ao transformar "objetos de estudo" em "sujeitos" contribui para a construção de uma história mais rica, mais viva, mais verdadeira.

Tais memórias dos entrevistados evocam um lugar que se perdeu com a guerra civil que assolou Angola entre 1975 e 2002. O longo conflito foi devastador para a infraestrutura do país destruindo a realidade conhecida pelos migrantes da descolonização. A sociedade angolana préguerra civil ficou registrada pictoricamente através de filmes propagandísticos da ditadura do Estado Novo, documentários como Angola: no outro lado do tempo (1996) de Mario Brito, um 
migrante da descolonização, fotografias de família, postais e revistas. Esses registros são suportes à memória, que é seletiva, portanto, passível de silenciamentos, esquecimentos. Apesar de alguns informantes reconhecerem a existência da discriminação racial naquela sociedade, predomina em seu discurso a ideia de uma sociedade semelhante a um paraíso, um paraíso colonial. Tal noção resiste ao tempo. Ainda hoje, em Portugal, há a noção de que o colonialismo português era diferente dos demais. Era um colonialismo soft (PIMENTA, 2006). Tal fato mostra que, ainda hoje, o luso-tropicalismo, cunhado por Gilberto Freyre e posteriormente apropriado pelo regime liderado por António de Oliveira Salazar, exerce uma influência na forma de conceber o antigo império.

Devido à sua importância econômica acreditamos que é válida uma maior atenção daqueles que se dedicam ao estudo de Angola à cidade do Lobito, bem como de outras urbes para além de Luanda, como, por exemplo Huambo (antiga Nova Lisboa), segunda maior cidades de Angola no período colonial, respectivamente merecem ser melhor estudadas não apenas devido às suas importâncias econômicas, mas também no que se refere à história do cotidiano.

\section{Referências Bibliográficas}

ANGOLA 70: Benguela-Lobito. Direção José Elyseu. Lisboa: Rádio e Televisão de Portugal, 1970. Disponível em: https://arquivos.rtp.pt/conteudos/benguela-lobito/. Acesso em 05 ago. 2019.

BARRETO, Isabel de Souza Lima Junqueira. Migrantes da descolonização: portugueses e lusoangolanos no Brasil (1974-1977). 2014. Tese (Doutorado em História) - Instituto de Ciencias Humanas e Filosofia, Universidade Federal Fluminense, Niterói, 2014. Disponível em: https://www.historia.uff.br/stricto/td/1577.pdf. Acesso em: 7 jun. 2021.

BITTENCOURT, Marcelo. O desporto nos países africanos: entre as práticas coloniais e os projectos de modernidade. $7^{\circ}$ CONGRESSO IBÉRICO DE ESTUDOS AFRICANOS, Lisboa, 2010. Disponível em: https://repositorio.iscteiul.pt/bitstream/10071/2229/1/CIEA7 2 BITTENCOURT Jogando\%20no\%20campo\%20 do\%20inimigo.pdf. Acesso em: 7 jun. 2021.

BOSSLET, Juliana Cordeiro de Farias. A cidade e a guerra: relaç̄ões de poder e subversão em São Paulo de Assunção de Luanda. Dissertação (Mestrado em História) - Instituto de Ciências Humanas e Filosofia, Universidade Federal Fluminense, Niterói, 2014. Disponível em: https://www.historia.uff.br/stricto/td/1786.pdf. Acesso em: 7 jun. 2021.

CASTELO, Cláudia. Passagens para a África: o povoamento de Angola e Moçambique com naturais da metrópole (1920-1974). Porto: Edições Afrontamento, 2007.

GARRIDO, Joan dei Alcàzar i. As fontes orais na pesquisa histórica: uma contribuição ao debate. Revista Brasileira de História. Memória história e Historiografia. ANPUH/MARCO Zero SCT CNPq FINEP set/92/ agost/93. Disponível em: 
https://www.anpuh.org/revistabrasileira/view?ID REVISTA BRASILEIRA=17. Acesso em 05 set. 2019.

LEYDESDORFF, Selma. Desafios do transculturalismo. In: FERREIRA, Marieta de Moraes; FERNANDES, Tania Maria; ALBERTI, Verena (Org.). História Oral: desafios para o século XXI. Rio de Janeiro: Editora Fiocruz/Casa de Oswaldo Cruz / CPDOC - Fundação Getúlio Vargas, 2000, p. 73-84.

MILHEIRO, Ana Vaz. Experiências em concreto armado na África portuguesa: influências do Brasil. In: Pós. Revista do Programa de Pós-Graduação em Arquitetura e Urbanismo da FAUUSP, n. 25, p. 56-79, 1 jun. 2009.

NETO, Maria da Conceição. Ideologias, Contradições e mistificações da colonização de Angola no século XX. Paris: Lusotopie, 1997.

PEIXOTO, Carolina Barros Tavares. Ser, não ser, voltar a ser ou tornar-se? Uma reflexão sobre a (re)inserção social dos angolanos de ascendência portuguesa à luz dos estudos pós-coloniais. 2015. Tese (Pós-colonialismos e Cidadania Global) - Faculdade de Economia, Universidade de Coimbra, Coimbra, 2015. Disponível em: https://eg.uc.pt/handle/10316/28147. Acesso em: 1 jun. 2021.

PIMENTA, Fernando Tavares. Angola no Percurso de um nacionalista: conversas com Adolfo Maria, Porto: Edições Afrontamento, 2006.

POLLAK, Michael. Memória e Identidade Social. In: Estudos Históricos, Rio de Janeiro, vol. 5, n. 10, 1992, p. 200-212.

RELÓGIO, André Tchoia; TAVARES, Fernando Oliveira; PACHECO, Luís. Importância do Caminho de Ferro de Benguela para o Desenvolvimento Regional, Cadernos de Estudos Africanos [online], 33, 2017. Disponível em: http://journals.openedition.org/cea/2243. Acesso em 25 mar. 2020.

REPÚBLICA PORTUGUESA - ESTADO DE ANGOLA. Informações Estatísticas 1972. Luanda: Direção Provincial dos Serviços de Estatística, 1973.

ROSEMAN, Mark. Memória sobrevivente: verdade e inexatidão nos depoimentos sobre o Holocausto. In: FERREIRA, Marieta de Moraes; FERNANDES, Tania Maria; ALBERTI, Verena (Org.). História Oral: desafios para o século XXI. Rio de Janeiro: Editora Fiocruz, Casa de Oswaldo Cruz, CPDOC - Fundação Getúlio Vargas, 2000, p. 123-134.

SELAU, Mauricio da Silva. História Oral: Uma metodologia para o trabalho com fontes orais. Esboços: histórias em contextos globais, Florianópolis, v. 11, n. 11, p. 217-228, jan. 2004. Disponível em: https://periodicos.ufsc.br/index.php/esbocos/article/view/486/9887. Acesso em: 13 ago. 2019.

SILVA, V. Cóias e.; TAVARES, A. Segadães. Caminho de Ferro de Benguela: patrimônio lusobritânico em solo angolano, Pedra $\mathcal{E}$ Cal, out - dez. 2002. Disponível em: http://www.gecorpa.pt/Upload/Revistas/Rev16 Revista Completa.pdf. Acesso em: 09 ago. 2019.

SMITH, Andrea L. (Ed.). Europe's invisible migrants. Amsterdam: Amsterdam University Press, 2003.

THOMPSON, Paul. A voz do passado: história oral. Rio de Janeiro: Paz e Terra, 2002. 
Sobre a autora:

Isabel de Souza Lima Junqueira Barreto: Graduada em História pela Universidade Federal Fluminense (2003); Mestra em Ciências Sociais (Área de Concentração Antropologia Cultural) pela Universidade Federal do Rio de Janeiro (2005); Doutora em História pela Universidade Federal Fluminense (2014).

Artigo recebido para publicação em: 6 de dezembro de 2019 .

Artigo aprovado para publicação em: 7 de junho de 2021.

\section{Como citar:}

BARRETO, Isabel de Souza Lima Junqueira Barreto. A Cidade de Lobito na memória de migrantes da descolonização de Angola residentes no Rio de Janeiro. Revista Transversos. Dossiê: Africanizar: resistências, resiliências e sensibilidades. Rio de Janeiro, no. 22, 2021. pp. 122-141. Disponível em: <http://www.epublicacoes.uerj.br/index.php/transversos>. ISSN 2179-7528. DOI: 10.12957/transversos.2021.47123

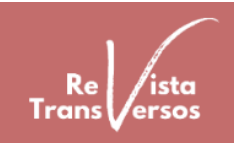

